MÁria Dobríová

Wydziak Filozoficzny Uniwersytetu Komeńskiego w Bratystawie

BratysŁaWa, Stowacja

dobrikova@fphil.uniba.sk

MÁRIO KYSEL'

Wydziak Filozoficzny Uniwersytetu Komeńskiego w Bratystawie

BratysŁaWa, StoWacja

kysel.mario@gmail.com

https://doi.org/10.17234/9789531755139.4

\title{
FAUNA WE FRAZEOLOGII STAROTESTAMENTOWYCH PRZYPOWIEŚCI
}

Przedmiotem badań niniejszego artykułu są podobieństwa i różnice w słowackich i polskich thumaczeniach tych wersetów Starego Testamentu, w których skład wchodzą frazeologizmy z komponentem zwierzęcym. Pierwsza część zawiera informacje o faunie z historycznego i symbolicznego punktu widzenia, jak również o frazeologii w Piśmie Świętym z naciskiem na słowacko-polski aspekt tłumaczeniowy. Główną część artykułu stanowi synchroniczna analiza konfrontatywna frazeologizmów biblijnych z komponentem zwierzęcym, które bezpośrednio wiążą się ze starotestamentowymi tekstami. W ramach badanej problematyki, oprócz absolutnej i częściowej ekwiwalencji poświęcono też uwagę kwestii istnienia jednosłownych ustalonych metafor odzwierzęcych, przede wszystkim specyficznej słowackiej metaforze czasownikowej (za)liškat'sa i jej przekładowym ekwiwalentom w polskiej wersji tekstów starotestamentowych.

Słowa kluczowe: Biblia, Stary Testament, fauna, frazeologia, frazeologizmy biblijne, ekwiwalencja frazeologiczna

Biblia jako tekst kultury, dokument historyczny i dzieło literackie o niezwykłym znaczeniu istnieje w dziejach ludzkości wiele stuleci. Kościoły chrześcijańskie a częściowo też religia żydowska (Stary Testament) uważają ją za dzieło natchnione przez Boga i za podstawę swojej wiary.

Chrześcijaństwo ma na terenach historycznego formowania się języków słowackiego i polskiego głębokie korzenie ${ }^{1}$, z uwagi na temat tego artykułu trzeba jednak podkreślić, że czterdziestoletni okres drugiej połowy XX wieku nie sprzyjał badaniu tematyki biblijnej. Przykładowo reedycje najobszerniejszego do tej pory zbioru frazeologii słowackiej Slovenské prislovia, porekadlá, úslovia a hádanky² Adolfa Petera Zatureckiego ukazywały się we wspomnianym okresie bez oryginalnego pierwszego rozdziału pt. Boh

$1 \quad$ Przykładowo papież Jan VIII w bulli założycielskiej Industriae tuae potwierdza powstanie w roku 880 biskupstwa nitrzańskiego (Nitra - miasto w zachodniej Słowacji). Było to najstarsze biskupstwo na terytorium środkowej Europy.

$2 \quad$ Stowackie przystowia, porzekadła, powiedzenia i zagadki. Po raz pierwszy tom wydano w roku 1987 w Czeskiej Akademii w Pradze. 
(Bóg), jak również bez części następnego rozdziału pt. Viera a mravy (Wiara i obyczaje). Rozdziały te włączono dopiero do ostatniego wydania z roku 2005 (Dobríková 2010: 468-469). Analogiczna sytuacja istniała w Polsce. Stanisław Koziara (2006: 76) w zwiazzku z tym konstatuje:

Wreszcie oceny dotychczasowych rejestrów tej części rodzimej frazeologii nie sposób oddzielić od czynników natury pozafilologicznej, których udział szczególnie w okresie 1945-1989 nie pozostawał bez wpływu na ilościową i jakościową stronę leksykograficznej kodyfikacji polskiej frazeologii biblijnej.

Kanonizowane księgi Pisma Świętego oddziaływały na poszczególne narody, wpływały na ich myślenie, stanowiły inspirację dla sztuki i naturalnie także dla języka, do którego przenikły nienacechowane stylistycznie jednostki leksykalne. Wśród nich na przykład słowacki rabin, w przekładach Biblii jako zwrot do Jezusa także Rabbi, polski rabin; słowacka i polska menora; słowacka synagóga, polska synagoga; ale także duża liczba słów oraz stałych związków wyrazowych o znaczeniu przenośnym - słowacka i polska Golgota oraz golgota ${ }^{3}$; słowacki farizej, polski faryzeusz; słowacki predpotopný, polski przedpotopowy'; słowacka manna nebeská, polska manna z nieba, manna niebieska; słowackie <vypit'> kalich horkosti $<a z ̌$ do dna>, polskie $<$ wypić $>$ kielich goryczy albo gorzki kielich $<a \dot{z}$ do dna $>$ itp.

Biblia stanowi bogate źródło do badań frazeologicznych. Frazeologizmy pochodzenia biblijnego są nieodłączną częścią zasobu słownictwa wszystkich języków słowiańskich. W większości przypadków są ekwiwalentne formalnie i znaczeniowo, jednak zdarzają się wśród nich także różnice, świadczące zarówno o odrębnym rozwoju poszczególnych języków, jak też o specyfice ich środków wyrazu (Skladaná 2011: 94). Teksty biblijne od wieków pozostają w centrum uwagi badań językoznawczych, przede wszystkim ze względu na potrzebę ich właściwego przekładu na dany język. Dlatego konieczna jest poprawna lektura i szczegółowa analiza tekstu oryginału, ponieważ tylko jego dogłębne badania umożliwią powstanie adekwatnych przekładów, które mają na celu oddziaływać na współczesnego czytelnika w taki sam sposób, w jaki teksty biblijne w językach oryginalnych oddziaływały na swoich pierwszych czytelników.

3 Golgota - 1. bibl. wzgórze za murami Jerozolimy kształtem przypominające czaszkę, na którym wykonywano egzekucje i gdzie, według Pisma Świętego, został ukrzyżowany Jezus Chrystus; 2. książk. Golgota i golgota - dotkliwe, długotrwałe cierpienie, męka; symbol cierpienia i bólu (na podstawie definicji ze SSSJ 2006: 1079 w przekładzie autorów).

$4 \quad$ Farizej (faryzeusz) - 1. hist. bibl. członek starożydowskiego stronnictwa religijno-politycznego surowo przestrzegającego żydowskich nakazów; 2. pejor. człowiek fałszywy, obłudny (na podstawie definicji ze SSSJ 2006: 956 w przekładzie autorów).

$5 \quad$ Przymiotnik w obu językach używany w znaczeniach: 1. pochodzący z okresu przed biblijnym potopem, np. predpotopné zviera (przedpotopowe zwierzę), 2. pejor. przestarzały, nienowoczesny, np. predpotopný účes (przedpotopowa fryzura), predpotopný klobúk (przedpotopowy kapelusz), predpotopné názory (przedpotopowe poglady) itp. (na podstawie definicji z KSSJ 2003: 555 i SSJ 1993: 449 w przekładzie autorów). 
W artykule podejmiemy zatem próbę językowej analizy tekstów biblijnych, przy czym skupimy się na aspekcie tłumaczeniowym i analizie ksiąg starotestamentowych. Naszym celem jest sprawdzenie, jaka fauna występuje w przypowieściach Starego Testamentu, w jaki sposób jest przedstawiona, a także czy poszczególni przedstawiciele świata zwierząt stali się w tekstach biblijnych częścią frazeologizmów oraz jak te konkretne jednostki interpretowane są w słowackich i polskich przekładach Biblii.

Zwierzęta w każdej kulturze stawały się symbolem pewnych cech. Na przykład kot w rozmaitych cywilizacjach symbolizował dobro lub zło. Starożytni Egipcjanie czcili go jako bóstwo. Wierzyli, że ma moc ochrony człowieka przed przeciwnościami losu. Jego obecność w domu oznaczała błogosławieństwo, zdrowie i długie życie. Również dla Greków i Rzymian był on wyjątkowym zwierzęciem domowym. W Japonii koty stanowiły ważną część obrzędów religijnych, miały też za zadanie chronić przed gryzoniami drogocenne kokony gąsienic jedwabnika morwowego oraz stare rękopisy w świątyniach. Gibkie ciało, eleganckie ruchy, umiłowanie swobody, czyli wszystko, co ludzie u kotów podziwiali, przesądziło o ich losie w średniowieczu. Inkwizycja orzekła, że są opętane przez złe duchy, gdyż mają w oczach ogień piekielny, wskazujący na związek z siłami nieczystymi. Ponieważ koty potrafią polować w zupełnych ciemnościach, w wierzeniach reprezentowały ciemne moce i miały ponoć brać bezpośredni udział w sabatach czarownic. Demoniczne właściwości przypisywano w szczególności czarnym kotom.

Ambiwalentne było również w historii symboliczne wyrażenie pychy, dumy. Współcześnie zarozumiałość i pycha są oceniane jako wady. Jednak nie zawsze były one tak negatywnie postrzegane. W starożytnej Grecji na przykład dumę uważano za cnotę, natomiast pokorę i skromność za cechy ludzi słabych, pozbawionych charakteru i zdolności. Etyka chrześcijańska dystansowała się od tego greckiego myślenia na korzyść pokory, podniesionej w chrześcijaństwie do rangi najwyższej cnoty moralnej. Pycha uważana jest z kolei za przyczynę każdego grzechu, interpretuje się ją jako bezpośredni bunt przeciw Bogu, stąd powoduje ona Jego gniew i zasłużoną karę. Pycha, wyniosłość człowieka utożsamiane są z wyglądem, zachowaniem i cechami pawia. Ale paw nie zawsze był symbolem o znaczeniu negatywnym. Na przykład w Indiach z uwagi na piękny, półokrągły ogon uważano go za symbol słońca. Początkowo chrześcijaństwo przejęło antyczne wierzenie, że krew pawia odpędza demony, z czasem jednak paw stał się ucieleśnieniem pychy i próżności.

Symbolika zwierząt nieprzypadkowo jest dziś tak bogata. Poszczególni przedstawiciele fauny reprezentowali rozmaite stereotypy od zarania religii czy literatury. $B i$ blia nie jest pod tym względem wyjątkiem. Barbara Szczepanowicz i Andrzej Mrozek (2007: 6) tak piszą o biblijnej symbolice zwierząt:

Zwierzęta w Biblii są ukazane w dwóch aspektach. Z jednej strony są przedstawione realia, czyli sposób życia i zachowanie zwierząt oraz ich występowanie i funkcjonowanie w życiu codziennym człowieka (to ostatnie dotyczy przede wszystkim zwierząt udomowionych), a z drugiej wybrane aspekty poszczególnych zwierząt 
stają się motywami literackimi i służą do zobrazowania rzeczywistości duchowej, sytuacji człowieka, całych narodów, uchwycenia specyfiki relacji zarówno międzyludzkich, jak i pomiędzy Bogiem a człowiekiem, lub między Bogiem a Jego narodem Izraelem. Coraz mniej zatem znajdujemy danych ściśle zoologicznych, a coraz więcej pojawia się alegorii, metafor i symboliki. Ta symbolika zostanie jeszcze bardziej rozwinięta w kulturach, które czerpią obficie z tradycji biblijnej, czyli w judaizmie i chrześcijaństwie. Jednak ta symbolika nie rodzi się z niczego, jest mocno zakorzeniona przede wszystkim w kulturze starożytnego Bliskiego Wschodu, ale też po trosze $\mathrm{w}$ tradycji hellenistycznej oraz $\mathrm{w}$ przedchrześcijańskich tradycjach schrystianizowanych ludów Europy, Azji i Afryki. Biblia to Księga pisana i czytana w kluczu przede wszystkim teologicznym. Nie są w niej zatem najważniejsze dane o charakterze zoologicznym. Istotniejsze jest usytuowanie motywów zwierzęcych w kontekście literackim, a przede wszystkim teologicznym.

Porównanie tekstów Starego Testamentu w językach słowackim i polskim wykazało stosunkowo dużo wzmianek o udomowionych i dziko żyjących zwierzętach, które w konkretnych wersetach w językach będących przedmiotem obserwacji nie zawsze są identyczne. Wprawdzie aby móc w pełni ocenić adekwatność przekładu, musielibyśmy znać oryginalny tekst literacki w języku hebrajskim bądź aramejskim, ewentualnie greckim czy łacińskim, niemniej jednak niektóre z różnic występujących między tymi przecież pokrewnymi językami są na tyle duże, że warto wymienić kilka przykładów:

- Vieš ty, kedy kozy skalné ${ }^{6}$ liahnu sa kedy lane vrhnú, spozoroval si? ${ }^{7}$

- Czy znasz poród koziorożca? Widziałeś rodzenie gazeli? ${ }^{8}$

Trzeba w tym miejscu zaznaczyć, że również w innych częściach Biblii znajdujemy podobne różnice w tłumaczeniu, na przykład: laň (łania) - gazela, srna (sarna) - gaze$l a^{9}$, a nawet srnka (sarenka) - kozica ${ }^{10}$. Da się je zapewne wyjaśnić gatunkowym podobieństwem łani i gazeli. Drugą przyczyną mógłby być inny język wyjściowy, z którego przekładano słowacką, ewentualnie polską wersję.

- Zajali tiež dvoje madiánskych kniežat, Oreba a Zeba. Oreba zabili na Havranej $\underline{\text { skale }}^{11}$ a Zeba zabili na Vlčom lise ${ }^{12}$. Potom prenasledovali Madiánčanov za Jordán a niesli Orebovu a Zebovu hlavu Gedeonovi.

\footnotetext{
6 Dosłowny przekład: kozy skalne.

7 Wszystkie słowackie przykłady tekstów starotestamentowych odpowiadają wersetom ze słowackich tłumaczeń Biblii podanych w literarturze na końcu artykułu.

$8 \quad$ Hi 39, 1.

9 Por. Prz 6, 5; Syr 27, 22 (w polskim przekładzie werset 20).

10 Por. Prz 5, 19.

11 Dosłowny przekład: Skała Gawrona.

12 Dosłowny przekład: Tłocznia Wilka albo Wilcza tłocznia.
} 
Ujęli przy tym dwóch dowódców madianickich: Oreba i Zeeba. Oreba zabili na skale Oreba, a Zeeba przy tłoczni Zeeba. Ścigali nadal Madianitów, a głowy Oreba i Zeeba przynieśli Gedeonowi za Jordan. ${ }^{13}$

W tym przypadku dużą pomocą byłaby znajomość oryginalnego tekstu hebrajskiego, która potwierdziłaby nasze badanie etymologiczne. Ponieważ porównanie polskiego i słowackiego przekładu sugerowało, iż imiona madianickich książąt są również grą językową i obrazową aluzją do gawrona i wilka, sprawdziliśmy, iż rzeczywiście, imię Oreb pochodzi prawdopodobnie od hebrajskiego orew ha-mizra, co oznacza gawrona, natomiast Zeeb wywodzi się z wyrazu ze'ew - wilk.

- V Samárii vypukol vel'ký hlad. Obliehal ju tak dlho, až bola oslia hlava po osemdesiat strieborných a štvrt' kabu holubieho trusu ${ }^{14}$ po pät' strieborných. Powstał zatem wielki głód w Samarii. Bo oto nieprzyjaciele oblegali ją tak iż głowa osła kosztowała osiemdziesiąt srebrnych syklów, a ćwiartka kaba dzikiej cebuli pięć syklów srebra. ${ }^{15}$

Mogłoby się wydawać, że w tym przypadku któryś z tłumaczy nie zrozumiał tekstu, ewentualnie popełnił inny błąd w przekładzie, gdyż odchody gołębia (holubi trus) i dziko rosnąco cebula nie mają z sobą nic wspólnego. Wyjaśnienie tego wersetu przynosi nota w słowackiej Biblii: „Holubi trus był to podobno jakiś rodzaj jadalnego warzywa. "'16 Polski przekład dzika cebula wydaje się w tym wypadku lepszy, ponieważ dla słowackiego czytelnika Pisma, który o tym warzywie nigdy nie słyszał, bez bliższych objaśnień znaczenie związku wyrazowego holubi trus będzie niejasne.

- Ktože slobodu dal oslu divému a kto onagrovi putá rozviazal?

Kto zebre wolno wypuszcza? Kto osła dzikiego rozwiąże? ${ }^{17}$

Vel'ký slovnik cudzich slov ${ }^{18}$ pod hasłem onager podaje: ,gatunek osła podobnego do konia, o wysokości zaledwie ok. 1 m" (1997: 859). Prawdopodobnie ponownie chodzi tu o pokrewieństwo gatunków, tym razem osła i zebry. Polski przekład tego wersetu jest naszym zdaniem bardziej zrozumiały dla czytelnika Biblii, ponieważ potrafi on sobie wyobrazić zebrę. Słowacki odbiorca natomiast nie zna onagera, jeśli zatem nie sięgnie do słownika wyrazów obcych, nie będzie wiedział, że chodzi o zwierzę kopytne.

\footnotetext{
Sdz 7, 25.

14 Dosłowny przekład: odchody gołębie.

$152 \mathrm{Krl} 6,25$.

16 Na podstawie Sväté písmo Starého a Nového zákona. Rím; Trnava Slovenský ústav svätého Cyrila a Metoda v Ríme; Spolok svätého Vojtecha, 1996, s. 662, przekład autorów.

17 Hi 39, 5.

18 Wielki słownik wyrazów obcych.
} 
- Vezmi vyberané barančatá ${ }^{19}$, naklad' podeň hŕbu dreva, nechaj vriet' jeho kúsky, i kosti nech sa $\mathrm{v}$ ňom uvaria!

Wybierz do tego najlepsze [sztuki] z mniejszego bydła, podłóż drwa pod spodem i spraw, by to wrzało i kipiało, tak by aż kości się rozgotowały. ${ }^{20}$

W sytuacji, kiedy nie mamy możliwości konfrontacji z tekstem oryginału, możemy zakładać, że chodzi o rogaciznę mniejszych rozmiarów, co w języku polskim przetłumaczono opisowo, podczas gdy w słowackim użyto konkretnej jednostki leksykalnej oznaczającej młode barana.

Warto w tym miejscu wspomnieć, że ze znacznymi różnicami spotykamy się przede wszystkim w thumaczeniu nazw zwierząt czystych i nieczystych w Księdze Powtórzonego Prawa oraz Księdze Kaplańskiej. Nie wspominamy przy tym różnic, które da się wyjaśnić podobieństwem gatunków (np. wót - byk), ale wskazujemy na te przypadki, w których mamy do czynienia z przedstawicielami zupełnie odrębnych gatunków. Są to przede wszystkim: żyrafa - kozica ${ }^{21}$, borsuk - królik ${ }^{22}$, kukułka $s o w a^{23}$. Zdarza się nawet sytuacja, kiedy w polskim wersecie Pwt 14, 5 pojawia się zwierzę daniel, które w słowackim przekładzie Starego Testamentu nie ma ekwiwalentu, również w żadnym wcześniejszym ani późniejszym wersecie, co ma miejsce w przypadku innych zwierząt (bocian, pelikán). Przytoczmy słowa Barbary Szczepanowicz i Andrzeja Mrozka (2007: 7):

O ile występowanie tam zwierząt takich, jak wielbłąd i świnia, a nawet nietoperz nie ulega wątpliwości, o tyle ogromna większość pozostałych jest wysoce niepewna - po prostu nie da się przy stanie aktualnej wiedzy powiedzieć, że w tym miejscu chodzi na pewno o takie, a nie inne zwierzę. [...] Należy jednak pamiętać, że jest to raczej do pewnego stopnia arbitralny wybór thumacza, gdyż tekst oryginalny nie daje podstaw do apodyktycznego stwierdzenia, że taki a nie inny gatunek tu występuje.

Jeśli chodzi o jednostki frazeologiczne pochodzenia biblijnego zawierające komponent zwierzęcy, w Starym Testamencie występują najczęściej absolutne (pełne) ekwiwalenty frazeologiczne. Chodzi o sytuację, w której jednostki frazeologiczne w języku słowackim i polskim mają identyczne znaczenie i jednakową strukturę, tj. układ komponentów. Niżej przedstawiamy najważniejsze z nich.

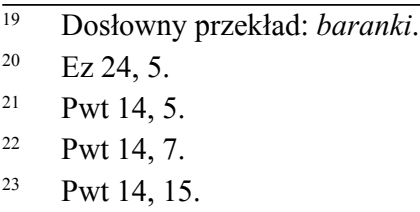


O stałym porównaniu frazeologicznym krotký ako baránok - potulny jak baranek znajdujemy wzmiankę w starotestamentowej Księdze Jeremiasza: „Ja som bol ako krotký baránok, vedený na zabitie; ani som nevedel, že stroja proti mne úklady ${ }^{{ }^{224}}, \mathrm{w}$ polskiej wersji: „Ja zaś jak potulny baranek, którego prowadzą na zabicie, nie wiedziałem, że powzięli przeciw mnie zgubne plany."W słowackiej frazeologii występuje również porównanie, które zawiera czasownik, natomiast przymiotnik jest komponentem fakultatywnym: byt'<krotký> ako baránok.

Kolejnym przykładem jest porównanie frazeologiczne byt' rýchly ako gazela być szybki jak gazela. Znajdziemy je w Drugiej Księdze Samuela: „Boli tam traja synovia Sarvie: Joab, Abisai a Asael. Asael bol rýchlonohý ako pol'ná gazela“25, w polskiej wersji: „Byli wśród nich również trzej synowie Serui: Joab, Abiszaj i Asahel. Asahel był szybki jak dzika gazela“, jak również w Pierwszej Księdze Kronik: „Aj z Gadovcov sa odrazili k Dávidovi do pevnosti na púšst' udatní hrdinovia, mužovia hotoví do boja, vyzbrojení štítom a kopijou; vyzerali ako levy, ale boli rýchli ako gazely na horách“26, w polskiej wersji: „Z Gadytów przyłączyli się do Dawida w warowni pustynnej dzielni wojownicy, żołnierze gotowi do walki, którzy celowali w posługiwaniu się tarczą i włócznią. $Z$ wyglądu podobni do lwów, byli szybkonodzy jak gazele na górach.“

Kiedy ktoś wyraża swoje myśli wprost, bez ogródek, mówi się o nim, że ma cięty lub ostry język. Frazeologizm mat' ostrý jazyk - mieć ostry język znany jest w języku słowackim także w postaci porównania: mat' jazyk <ostrý> ako britva (osa, žihadlo). W przypadku porównania chodzi o wskazanie podobieństwa do konkretnego, ostrego i kłującego przedmiotu, na podstawie czego jednostki mat' ostrý jazyk-mieć ostry język nie można zaliczyć do frazeologizmów biblijnych z komponentem zwierzęcym. Ale według Biblii ostry język miał przecież wąż, co potwierdza werset z Księgi Psalmów:

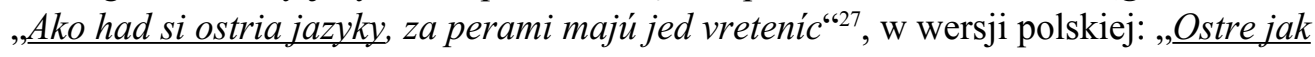
u węża ich jezzyki, a jad żmijowy pod ich wargami.“ Możliwe, że ten związek wyrazowy pierwotnie brzmiał: mieć język ostry jak waż, ale z biegiem czasu komponent waż został $\mathrm{z}$ niego usunięty. Z biblijną historią stworzenia pierwszych ludzi wiąże się jednostka frazeologiczna hadie plemeno, która w języku słowackim ma dwa znaczenia: 1) „fałszywi ludzie”, 2) „kobiety”, podczas gdy jej ekwiwalent w języku polskim, wężowe plemię, ma tylko pierwsze $\mathrm{z}$ wymienionych znaczeń.

Osobę zwinną, która robi wielkie kroki czy wręcz skacze, często porównuje się do jelenia, co wyraża kolejne porównanie frazeologiczne skákat' ako jelen̆ - skakać jak jeleń. Wzmiankę o nim zawiera także Księga Izajasza: „st’a jeleň bude skákat' chromý. “28 W polskim przekładzie: „Wtedy chromy wyskoczy jak jeleń.“

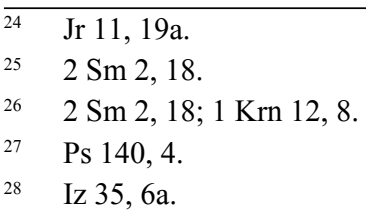


Nazwa owca pojawia się w wielu związkach frazeologicznych pochodzenia biblijnego. Pierwszy z nich to chodit' (túlat') sa ako ovce bez pastiera - chodzić jak owce bez pasterza, używany dla określenia ludzi niemających przywódcy, szukających właściwej drogi lub niemogących jej znaleźć. Przykład znajdziemy w Pierwszej Księdze Królewskiej. ${ }^{29}$ Kolejną motywacją powstania biblijnego frazeologizmu z komponentem owca jest starotestamentowy werset o zabłąkanej owcy. W Księdze Psalmów pisze się: „Blúdim ako ovca, čo sa stratila; hladaj svojho sluhu, lebo nezabúdam na tvoje predpisy“ ${ }^{“ 30}$, w polskiej wersji: „Błądzę jak owca, która zginęła; szukaj swego sługi, bo nie zapominam o Twoich nakazach." Chodzi zatem o frazeologizm byt' (chodit') ako bludná ovca - być (chodzić) jak btędna owca, który pojawia się także w innych częściach Starego Testamentu. ${ }^{31}$ Trzecim przykładem jest związek frazeologiczny viest' niekoho ako ovcu (baránka) na zabitie - prowadzić kogoś jak owcę (baranka) na rzeź (zabicie) ${ }^{32}$. W Księdze Jeremiasza odnajdujemy zapis: „Ty ma však, Pane poznáš, vidíš ma, skúmaš, aké mám voči tebe srdce. Ved’ ich ako ovce

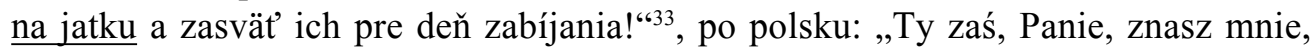
patrzysz na mnie, badasz serce moje, ono jest z Tobą. Oddziel ich jak owce na rzeź, przygotuj ich na dzień mordu!“‘

Do kategorii absolutnych ekwiwalentów frazeologicznych należy również starsza jednostka Balámova oslica. Określano nią człowieka pokornego, w języku polskim oślica Balaama. Historia ta pochodzi z Księgi Liczb. ${ }^{34}$ Kiedy Balaam jechał na oślicy do króla Moabu, po drodze anioł Boży ostrzegł go przed grożącym mu niebezpieczeństwem. Sam Balaam nie mógł wszakże dostrzec anioła, ale jego oślica - tak. Za każdym razem, gdy go zobaczyła, schodziła z drogi lub przyciskała się do muru, za co ją Balaam okrutnie bił. Zwierzę jednak z pokorą i cierpliwością znosiło niesprawiedliwy gniew pana, który zrozumiał całą sytuację dopiero wówczas, gdy anioł w końcu objawił się i jemu. Frazeologizm ten zarówno w języku polskim, jak i słowackim nie jest dziś używany, zalicza się do książkowych. Warto jednak w tym miejscu wspomnieć o pewnym aspekcie rodzajowym, chociaż rozróżnienie to nie pochodzi bezpośrednio z Biblii. Oślica uosabia tu pokorę i posłuszeństwo, czego potwierdzenie znajdziemy i w Nowym Testamencie - to na oślicy Jezus Chrystus wjeżdżał do Jerozolimy. Natomiast nazwa samca - osiot - pojawia się już w związkach frazeologicznych z negatywną konotacją: słowackie hlúpy ako osol, polskie głupi jak osiot. Jak więc widzimy, również kwestia rodzaju (w tym wypadku płci zwierzęcia) może być istotna dla właściwego wyjaśnienia znaczenia frazeologizmu.

\footnotetext{
$29 \quad 1 \mathrm{Krl} 22,17$.

30 Ps $119,176$.

31 Por. Iz 53, 6.

32 W wydaniach Biblii, z których korzystaliśmy, występuje częstsza współcześnie forma frazeologizmu z komponentem na rzeź, ale w starszych wydaniach Biblii można spotkać również postać na zabicie.

33 Jr 12, 3 .

34 Por. Lb 22, 21-33.
} 
Oprócz ekwiwalencji absolutnej znajdziemy też w Starym Testamencie liczne przykłady ekwiwalencji częściowej w zakresie frazeologii z komponentem zwierzęcym. ${ }^{35}$

Księga Rodzaju w historii o złożeniu ofiary z Izaaka ${ }^{36}$ zawiera wzmiankę o ofierze całopalnej, która miał być, według Izaaka, baranek (w słowackiej wersji Biblii, w polskiej znajdziemy thumaczenie jagnię. Czytamy tam: „Izaak odezwał się do swego ojca Abrahama: «Ojcze mój!» A gdy ten rzekł: «Oto jestem, mój synu» - zapytał: «Oto ogień i drwa, a gdzież jest jagnię na całopalenie?» Abraham odpowiedział: «Bóg upatrzy sobie jagnię na całopalenie, synu mój»”). ${ }^{37}$ Polskim ekwiwalentem słowackiego frazeologizmu obetný baránok o znaczeniu „,człowiek, na którego zrzuca się cała odpowiedzialność za coś”, jest jednostka kozioł ofiarny. Baranek i kozioł nie mają z sobą aż tyle wspólnego, aby chodziło tu o przypadkową zamianę. Można to jednak wyjaśnić następująco: Izraelici składali Bogu liczne ofiary, przy czym jest tu istotne, że chodziło o ofiarę całopalną. Jedną z nich była też ofiara za grzech, która ,związana była $\mathrm{z}$ większym poczuciem winy (Kpł 5). Rytuał był bardzo podobny do ofiary przebłagalnej, a składającym mogły być tylko osoba prywatna. Jedynym możliwym w tej ofierze zwierzęciem był baranek“" (Szczepanowicz i Mrozek 2007: 217). To oznacza, że baranek był jednym z częściej składanych w ofierze zwierząt, na tej podstawie wywodzimy motywację słowackiego związku frazeologicznego. Jeśli chodzi o polski odpowiednik, dowiadujemy się, że ,jednak należy zwrócić uwagę na kozła ofiarnego przyjmującego grzechy całej społeczności. Zwyczaj i tradycja obarczania kozła wina społeczności są obecne we wszystkich kulturach, począwszy od rytuałów starożytnej Babilonii po współczesną Japonię, a określenie „kozioł ofiarny” stało się przysłowiowe" (tamże: 219).

Jak zatem widać, także kozioł był zwierzęciem ofiarnym, ale - uwzględniając kontekst historyczny - składany był w ofierze za grzechy wszystkich, nie pojedynczych osób, jak w przypadku baranka. Na tej podstawie wnioskujemy, że zjawisko ofiary za zbiorowość stanowiło w języku polskim silniejszą motywację związku frazeologicznego niż ofiara za jednostkę. Należy jeszcze wspomnieć, iż frazeologizm smrdiet' ako cap - śmierdzieć jak cap (kozioł), który wprawdzie nie ma ścisłego związu z Biblia, spotykamy w obu językach. W języku polskim wyraz kozioł występuje zatem w dwóch frazeologizmach mających jednakże różną konotację: wyraźnie negatywną w przypadku śmierdzieć jak cap (koziol) i w zasadzie pozytywną we frazeologizmie koziot ofiarny.

Kolejnym znanym i współcześnie często używanym frazeologizmem z komponentem zwierzęcym, mającym źródło w starotestamentowej przypowieści, jest jednostka

\footnotetext{
35 W językach słowackim i polskim istnieje wiele frazeologizmów zawierających badany typ komponentu, niemających jednakże związku z kontekstem biblijnym, np.: vystrájat’ako opitý cap - narozrabiać jak pijany zajac, studený ako žaba - zimny jak ryba, ani ryba, ani rak - ni pies, ni wydra. Zdarzają się też przypadki, kiedy w jednym z języków dany ekwiwalent nie zawiera komponentu zwierzęcego, np.: chodit' ako spomalený film - tazić jak senna mucha, vrieskat' (revat') ako pavián - drzeć się jak stare prześcieradto, mlčat’ ako ryba-milczeć jak grób itp.

36 Por. Rdz 22, 1-14.

37 Tamże, 7-8.
} 
zlaté tel'a - zloty cielec, która symbolizuje mamonę lub jakiś obiekt nadmiernego kultu materialnego, ewentualnie też lukratywne źródło pieniędzy. Ten związek wyrazowy pochodzi z zawartej w Księdze Wyjścia opowieści o tym, jak Mojżesz wspiął się na górę Synaj, gdzie otrzymał od Boga Dziesięć Przykazań. W tym czasie lud się od niego odwrócił i postawił posag cielca ze złota, któremu oddawał cześć. ${ }^{38}$ Mamy tu do czynienia z częściowym ekwiwalentem frazeologicznym, gdyż w języku słowackim jest rzeczownik w rodzaju nijakim (tel'a), podczas gdy w języku polskim - w męskim (cie$l e c$ ), przy czym wyraz cielec nie jest współcześnie używany w innym niż tym właśnie frazeologicznym kontekście, tzn. nie w odniesieniu do zwierząt.

Ciemny kolor włosów jest w Starym Testamencie porównany do czarnego koloru piór gawrona, jak w Pieśni nad pieśniami: „Jeho hlava je zlato, rýdze zlato, jeho kučery st'a riasy na datli, čierne jak havrany“"39. W polskiej wersji natomiast czytamy: „Głowa jego - najczystsze złoto, kẹdziory jego włosów jak gałązki palm, czarne jak kruk. “ Podczas gdy w języku słowackim występuje porównanie: mat' vlasy čierne ako havran, $\mathrm{w}$ polskim znajdujemy jego częściowy ekwiwalent, w którym komponentem zwierzęcym jest spokrewniony z gawronem kruk: mieć wtosy czarne jak kruk. $\mathrm{Z}$ tych porównań wywodzą się także przymiotniki używane najczęściej właśnie w odniesieniu do koloru włosów: havranie vlasy - krucze lub kruczoczarne włosy.

Znanym frazeologizmem biblijnym jest w języku słowackim jama levová lub byt (ocitnút'sa) vjame levovej, dostat'sa (spadnút') do jamy levovej (Skladaná 1999: 45). Ma on swoje źródło w Księdze Daniela. Prorok Daniel został wtrącony do jamy z lwami, gdyż przepowiadał królowi, że czeka go marny los, o ile nie zacznie żyć bogobojnie. Proroctwo tak rozgniewało króla, że ukarał w ten sposób Daniela za to, iż śmiał go krytykować. Z woli Boga jednak lwy nie skrzywdziły proroka. Jama levová oznacza współcześnie jakiekolwiek niebezpieczeństwo zagrażające człowiekowi. W polskim przekładzie Biblii mamy jednak nie jamę, lecz jaskinię. Dla porównania: „Nato král' vydal rozkaz, priviedli Daniela a hodili ho do levovej jamy. Král' povedal Danielovi: Nech t’a vyslobodí tvoj Boh, ktorého vytrvalo ctíš!”, w polskiej wersji: „Wtedy król wydał rozkaz, by sprowadzono Daniela i wrzucono do jaskini lwów. Król zwrócił się do Daniela i rzekł: «Twój Bóg, któremu tak wytrwale służysz, uratuje cię».“40

Przykładem częściowego ekwiwalentu frazeologicznego z komponentem lev/leví jest $\mathrm{w}$ języku słowackim frazeologizm dotyczący odwagi. O człowieku odważnym mówi się, że ma levie srdce. Również ten związek frazeologiczny ma swe źródło w Biblii, a ściśle w Drugiej Księdze Samuela ${ }^{41}$, jego ekwiwalent w polskim przekładzie brzmi serce lwa. Trzeba jednak zaznaczyć, że i język polski zna określenie lwie serce, utrwalone chociażby w przydomku angielskiego króla Ryszarda I Lwie Serce.

\footnotetext{
$38 \quad$ Por. Rdz 32.

39 PnP 5, 11.

40 Dn 6, 17.

$412 \mathrm{Sm} \mathrm{17,} 10$.
} 
W potocznym języku słowackim często usłyszeć można wyzwisko: Hovädo! To wyraz ekspresywny i już w Biblii był jako taki postrzegany w przypadku, kiedy odnosił się do człowieka. W Księdze Hioba jest zapis: „Prečo sme za hovädá pokladaní? Prečo sme v tvojich očiach nečistí?". W polskim przekładzie Pisma znajdujemy natomiast takie thumaczenie: „Czyśmy podobni do zwierząt, jesteśmy nieczyści w twych oczach?“42 Jak widać, $\mathrm{w}$ języku polskim ekwiwalentem w tym wersecie jest słowo zwierzę. We współczesnym języku słowackim także natrafimy na zgodną konotację, ale o słabszym zabarwieniu ekspresywnym, co widać w porównaniu: správat' sa ako hovädo, správat'sa ako zvie$r a$. Podobne rozróżnienie nacechowania emocjonalnego porównań spotykamy w języku polskim: zachowywać się jak bydlę, zachowywać się jak zwierzę. Warto w tym miejscu dodać, że i w polszczyźnie funkcjonuje obelga: Bydlę!, która odpowiada słowackiemu: Hovädo!

W Księdze Wyjścia odnajdujemy takie słowa: „Ale u Izraelitov ani pes nezaštekne ani na človeka, ani na dobytča, aby ste poznali, že Pán obdivuhodne rozlišuje Egypt'anov od Izraelitov“433 , po polsku: „U Izraelitów nawet pies nie zaszczeka ani na ludzi, ani na bydło, abyście poznali, że Pan uczynił różnicę między Egipcjanami a Izraelitami.“ W tym wersecie mają swe źródło frazeologizmy ani pes sa o niekoho, niečo neobzrie; ani pes nezabrě̌e (nezašteká) na niekoho, na niečo - pies z kulawq nogq nie przyjdzie (nie wspomni, nie zadba).

W poprzedniej części artykułu poddaliśmy analizie pełne ekwiwalenty frazeologiczne, które zawierają nazwę zwierzęcia. Wspomniano tam również frazeologizmy dotyczące węża, który w niektórych kulturach uważany jest za symbol mądrości, bogactwa czy nieśmiertelności, ale w kulturze chrześcijańskiej uosabia zło i pokuszenie. To właśnie wąż namówił pierwszych ludzi do popełnienia grzechu pierworodnego. Księga Rodzaju przedstawia go następująco: „No had bol l'stivejší ako všetky pol’né zvieratá, ktoré urobil Pán..." ${ }^{44}$, w polskiej wersji: „A wąż był bardziej przebiegły niż wszystkie zwierzęta lądowe, które Pan Bóg stworzył.“ Do częściowych ekwiwalentów w językach słowackim i polskim należą frazeologizmy: človek ako had lub úlisný ako had - chytry jak waż, mające znaczenie ,przebiegły, fałszywy, podstępny człowiek“". We frazeologii słowackiej fałszywy człowiek porównywany jest także do kota - falošný ako mačka, chytry zaś i przebiegły - do małpy: chytrý ako opica.

Do tej grupy częściowych ekwiwalentów z komponentem derywowanym od rzeczownika had (waż) należy też słowacki frazeologizm hadie jazyky (dosłownie: wężowe języki), mający znaczenie „ludzie fałszywi, oczerniający innych, nikczemni, podli”. Jego polskie odpowiedniki zawierają nazwy innych przedstawicieli fauny, przy czym ich podstawową formą jest mianownik liczby pojedynczej: jaszczurczy (psi, smoczy) język.

\begin{tabular}{ll}
\hline 42 & Hi 18, 3. \\
43 & $\operatorname{Rdz} 11,7$. \\
44 & $\operatorname{Rdz} 3,1$.
\end{tabular}


Metaforyczność jako uzualny atrybut komunikacji językowej ma swe źródło w ustalonych empirycznych stosunkach, wzorach i modelach myślenia (Dolník 2003: 68), które przekazują kulturalno-idiomatyczne informacje o abstrakcyjnych i wyobrażeniowych stereotypach tudzież językowym obrazie świata danego społeczeństwa. Dzięki wyobraźni człowieka i jego zdolności do myślenia abstrakcyjnego nie tylko związi wyrazowe, ale także liczne jednowyrazowe środki językowe mają charakter metonimicznego skrótu (Dobríková 2009: 162-164). W słowackim językoznawstwie na frazeologiczny charakter jednowyrazowej ustalonej metafory w postaci czasownika jako pierwszy zwrócił uwagę František Miko, który w związku z jednostkami typu popálit' $s a^{45}$ „Znaleźć się w nieprzyjemnej sytuacji, źle na czymś wyjść”, vyhoriet ${ }^{46}$ „ponieść porażkę”, rozpálit’ $s a^{47}$ „rozgniewać się” konstatuje, że „funkcją, swoim etosem i idiomatycznym charakterem ewidentnie przypominają swoich dwu- i więcejwyrazowych «partnerów»" (Miko 1989: 25), czyli jednostki frazeologiczne. Uczestnicy aktu komunikacji w zależności od kontekstu dokładnie rozróżniają, czy na przykład w przypadku czasownika popálit' sa chodzi o jego dosłowne znaczenie „wyrządzić sobie krzywdę, sprawić ból ogniem", czy też znaczenie przenośne wymienione wyżej.

W języku polskim i słowackim istnieją metafory czasownikowe, które nie powstały jedynie $\mathrm{w}$ wyniku prostego przeniesienia znaczenia na bazie ekspresywności czy pragmatycznego podejścia do wyrażanego pojęcia, ale wywodzą się z doświadczenia empirycznego lub z istniejących wcześniej jednostek frazeologicznych. Należą do nich także ekspresywne czasowniki odzwierzęce, na przykład słowackie opičit'sa, polskie matpować „naśladować kogoś, przedrzeźniać”; słowackie naježit’ sa, zježit’ sa, polskie najeżyć się, zjeżyć się „zezłościć się, zdenerwować się”; słowackie papagájovat', polskie papugować ${ }^{48}$ „mechanicznie powtarzać”; słowackie kuvikat „,przepowiadać nieszczęście”, zvlčit’ sa „stać się dzikim”"49; polskie szarogęsić się "zachowywać się samowolnie, rządzić się, panoszyć się”, rozindyczyć się „wpaść w złość”. Do tej kategorii zalicza się także słowacki czasownik zwrotny lískat'sa „przymilać się, podlizywać się, schlebiać", który bezpośrednio wiąże się z porównaniem byt prefikaný ako liška, w języku polskim być chytry (przebiegly) jak lis. Frazeologizm ten powstał na podstawie obserwacji empirycznej i związanego z nią wyobrażenia, że lis jest ssakiem przebiegłym, potrafiącym w sposób przemyślany a niekiedy podstępny łowić zwierzynę, czyli

$\overline{45} \quad$ Dosłowny przekład: oparzyć się. W języku polskim używa się w tym znaczeniu czasownika sparzyć się. Por. też przysłowie: Kto raz się sparzy, na zimne dmucha.

46 Dosłowny przekład: spalić się.

47 Dosłowny przekład: rozpalić się.

48 Czasownik wywodzi się z frazeologizmu powtarzać jak papuga, czyli „mechanicznie powtarzać“.

49 Kuvik to w słowackim nazwa ptaka z rodziny puszczykowatych, pójdźki. W języku polskim w tym znaczeniu używa się najczęściej czasownika krakać. Zvlčit’ sa (w dosłownym przekładzie zwilczé́) oznacza tyle, co polski czasownik zdziczeć. Jak widać, polskie odpowiedniki tych wyrazów również powstały w wyniku obserwacji świata zwierząt.

50 Czasownik ma swe źródło we frazeologizmie rzqdzić się jak szara gęś, mającym takie właśnie znaczenie. 
uzyskiwać korzyść. Stąd wyprowadzono też później wspomniany czasownik niedokonany lišskat' sa i jego dokonaną formę zalískat'sa. W Starym Testamencie znajduje się pięć wersetów zawierających ten czasownik w różnej formie, dla zilustrowania podajemy tylko trzy przykłady:

- Ale on zveleboval krála, aby sa mu zalíškal, pričom sa tváril ako vel'mož. Tak získal vel'kňazstvo pre seba a nadhodil nad Jasona tristo talentov striebra.

On zaś stawiony przed króla olśnił go pozorami wpływów, zdobył więc dla siebie godność arcykapłańska, ofiarowując o trzysta talentów więcej od Jazona. ${ }^{51}$

- Št’astný si, Izrael! Kto sa ti vyrovná? Lud, ktorého spásou je Pán! On je tvoj štít ochranný, on je tvoj meč slávny; nepriatelia sa ti budú líškat' a ty im budeš šliapat' po šijach.

Izraelu, tyś szczęśliwy, któż tobie podobny? Narodzie, zbawiony przez Pana, Obrońca twój tobie pomaga, błogosławi zwycięski twój miecz. Wrogowie słabna przed tobą, ty zaś wyniosłość ich depczesz. ${ }^{52}$

- Hovorte Bohu: Aké úžasné sú tvoje diela. Pre tvoju nesmiernu moc budú sa ti líškat' tvoji nepriatelia.

Powiedzcie Bogu: Jak zadziwiające są Twoje dzieła! Z powodu wielkiej Twej mocy muszą $\mathrm{Ci}$ schlebiać Twoi wrogowie. ${ }^{53}$

W księgach Starego Testamentu wymieniono sto sześćdziesiąt pięć zwierząt, przy czym ogólna liczba wzmianek o nich wynosi ponad dwa tysiące sto $^{54}$. Liczba samych wersetów jest mniejsza, ponieważ w jednym wersecie pojawiają się czasem jednocześnie nazwy dwóch lub więcej zwierząt. Do sumy tej wliczyliśmy także nazwy młodych zwierząt, zdrobnienia oraz inne derywaty. Nie wliczaliśmy jednakże nazw rodzajowych, takich jak na przykład ssak, bydto itp., podobnie jak nazw istot mitologicznych, jak smok, jednorożec itp.

Frazeologizmy pochodzenia biblijnego są nieodłączną częścią zasobu leksykalnego języków słowiańskich (podobnie jak innych języków europejskich). Ponieważ słowacki i polski są genetycznie bliskimi językami, jest naturalne, że większość badanych przez nas frazeologizmów starotestamentowych jest zgodna pod względem formy i treści. Jednakże zaobserwowaliśmy także pewne różnice, co świadczy nie tylko o niezależnym rozwoju obu języków, ale również o specyficznym podejściu tłumaczy tekstów biblijnych.

\footnotetext{
$2 \operatorname{Mch} 4,24$.

Pwt 33, 29.

Ps 66, 3.

54 Do najliczniej występujących zwierząt należą: owca (235), baran (159), w formie deminutywnej baranek (141), koń (146), lew (119), byk (110), w formie deminutywnej byczek (107), osioł (109), koziol (88), waż (47), wielbład (60). Warto zauważyć, że wąż, który jest symbolem zła i przedstawicielem diabła, pojawia się czterokrotnie rzadziej niż owca, która uosabia cechy pozytywne.
} 
Po frazeologię biblijną także współcześnie chętnie sięgają w swoich tekstach publicyści i pisarze, odwołując się na przykład do różnych cytatów z Biblii. W artykule wskazaliśmy na konieczność dobrego poznania wszelkich niuansów tekstu wyjściowego i celowego, czyli, uwzględniając aspekt naszych badań, tych ustępów przypowieści starotestamentowych, które zawierają frazeologizmy z komponentem zwierzęcym, a które mogłyby sprawić potencjalny problem podczas tłumaczenia dzieł literackich lub też fragmentów biblijnych w ramach współczesnego słowackiego albo polskiego dyskursu medialnego.

\section{LITERATURA}

Biblica. Biblický atlas. 2007. Praha: Fortuna Libri.

Biedermann, Hans. 1992. Lexikón symbolov. Bratislava: Obzor.

Buffa, Ferdinand. 1994. K charakteristike pol'ských a slovenských prirovnaní. W: Studia Linguistica Polono-Slovaca 4. Ripka, Ivor. (red.) Bratislava: Veda. 42-51.

Buffa, Ferdinand. 2001. Z pol’sko-slovenských lexikálnych vzt’ahov. Prešov: Náuka.

Dobrikova, Maria. 2010. Biblejskite sužeti vav frazeologičnija fond na zapadnoslavianskija ezikov areal. W: Naučni trudove (Filologija). Čolakova, Žoržeta. (red.). 1: 468-475.

Dobríková, Mária. 2009. Konceptuálna analýza frazém s významom bohatstvo: chudoba. W: Slovacite i slovakistika v Balgarija. Ivanova, Cenka; Konstantinova, Daniela (red.). Sofia: Stigmati. 162-176.

Dobríková, Mária. 2007. Pýcha peklom dýcha. Slovenské zahraničie. 3: 18.

Dobríková, Mária. 2009. Nekupujte mačku vo vreci. Slovenské zahraničie. 2: 20.

Dolník, Juraj. 2003. Lexikológia. Bratislava: Univerzita Komenského.

Heriban, Jozef. 2011. Úvody kjednotlivým spisom Svätého písma Starého i Nového zákona. Rím - Trnava: Slovenský ústav sv. Cyrila a Metoda - Spolok svätého Vojtecha.

Koziara, Stanisław. 2006. Polska frazeologia biblijna - stan i perspektywy opisu. LingVaria. 1: 73-80.

Leščinský, Jozef. 2008. Biblia a inkulturácia. W: Biblia w kulturze świata. Jelonek, Tomasz (red.). Kraków: Wydawnictwo Naukowe Papieskiej Akademii Teologicznej. 43-50.

Miko, František et al. 1989. Frazeológia v škole. Bratislava: Slovenské pedagogické nakladatel'stvo.

Skladaná, Jana. 1993. Niektoré východiská porovnávacej frazeológie. Slavica Slovaca. 28: 55.

Skladaná, Jana. 1998. Slovenské frazémy krest’anského pôvodu v slovanskom kontexte. W: XII. medzinárodný zjazd slavistov v Krakove. Príspevky slovenských slavistov. Dorula, Ján (red.). Bratislava: Slovenský komitét slavistov - Slavistický kabinet Slovenskej akadémie vied. 133-141.

Skladaná, Jana. 2011. Niektoré slovenské frazémy v slovanskom kontexte. W: Philologica LXVII. Dobríková, Mária (red.). Bratislava: Univerzita Komenského. 89-98. 
Skladaná, Jana. 1999. Slová z hlbín dávnych vekov. Bratislava: GRAND MULTITRADE.

Sväté písmo Starého a Nového zákona. 1996. Rím - Trnava: Slovenský ústav sv. Cyrila a Metoda - Spolok svätého Vojtecha.

Sväté písmo Starého a Nového zákona. 2011. Rím - Trnava: Slovenský ústav sv. Cyrila a Metoda - Spolok svätého Vojtecha.

Szczepanowicz, Barbara; Mrozek, Andrzej. 2007. Atlas zwierzat biblijnych. Miejsce w Biblii i symbolika. Kraków: Wydawnictwo WAM.

Wajda, Anna Maria. 2008. Zwierzęta czyste i nieczyste w Biblii. W: Biblia w kulturze świata. Jelonek, Tomasz (red.). Kraków: Wydawnictwo Naukowe Papieskiej Akademii Teologicznej. 127-149.

Záturecký, Adolf Peter. 2005. Slovenské príslovia, porekadlá, úslovia a hádanky. Bratislava: Slovenský Tatran.

\section{SŁOWNIKI}

Buffa, Ferdinand. 1998. Frazeologický slovnik pol’sko-slovenský. Prešov: Náuka. [FSPS]

Godyń, Jan. 1980. Od Adama i Ewy zaczynać. Mały słownik biblizmów języka polskiego. Warszawa: Spółka Wydawniczo-Księgarska. [MSBJP]

Krátky slovnik slovenského jazyka. 2003. Kačala, Ján; Pisárčiková, Mária; Považaj, Matej (red.). Bratislava: Veda. [KSSJ]

Skorupka, Stanisław. 1985. Stownik frazeologiczny języka polskiego A-P. Warszawa: Wiedza Powszechna. [SFJP A-P]

Skorupka, Stanisław. 1985. Słownik frazeologiczny języka polskiego $R-\dot{Z}$. Warszawa: Wiedza Powszechna. [SFJP R-Ż]

Slovník slovenského jazyka. 1959-1968. Peciar, Štefan (red.). Bratislava: Vydavatel'stvo Slovenskej akadémie vied. [SSJ]

Slovnik súčasného slovenského jazyka. 2006. Buzássyová, Klára; Jarošová Alexandra (red.). Bratislava: Veda. [SSSJ]

Šaling, Samo et al. 1997. Vel'ký slovník cudzich slov. Vel'ký Šariš: SAMO. [VSCS]

Vragaš, Štefan et al. 2006. Teologický a náboženský slovník A-K. Trnava: Spolok svätého Vojtecha. [TaNS 1]

Vragaš, Štefan et al. 2008. Teologický a náboženský slovník L-Ž. Trnava: Spolok svätého Vojtecha. [TaNS 2] 


\section{SUMMARY}

\section{FAUNA IN PHRASEOLOGY OF OLD TESTAMENT PARABLES}

The authors of this paper examine concordances and differences of Slovak and Polish translations of those verses of the Holy Scripture in which phrasal idioms with animal component occur. In the introduction part they provide information on fauna from the historical and symbolic point of view, as well as on phraseology in the Holy Scripture, emphasizing the aspect of the SlovakPolish translation. The paper focuses on the synchronic confrontational analysis of biblical phrasal idioms with animal component that are related to the Old Testament texts.

Key words: Bible, Old Testament, Phraseology, Biblical phrasemes, Phraseological equivalence 